\title{
Tumor necrosis factor-alpha (TNF- $\alpha$ ) levels in aqueous humor of primary open angle glaucoma
}

This article was published in the following Dove Press journal:

Clinical Ophthalmology

28 April 201 I

Number of times this article has been viewed

\author{
Sankarathi Balaiya \\ Jayson Edwards \\ Tina Tillis \\ Vijay Khetpal \\ Kakarla V Chalam \\ University of Florida College \\ of Medicine, Department of \\ Ophthalmology Jacksonville, FL, USA
}

Purpose: Tumor necrosis factor alpha (TNF- $\alpha$ ), a macrophage/monocyte derived pluripotent cytokine is associated with tissue ischemia, neuronal damage and remodeling. The physiological level of TNF- $\alpha$ in aqueous humor of normal and glaucomatous eyes is unknown. In this study, we evaluated the TNF- $\alpha$ levels in aqueous in patients with primary open angle glaucoma (POAG) and compared them to controls.

Methods: $50-100 \mu \mathrm{L}$ of undiluted aqueous humor samples were obtained from eyes of 32 POAG patients who underwent cataract extraction, trabeculectomy or aqueous shunt implantation. Controls were obtained from 32 normal subjects who underwent routine cataract surgery. TNF- $\alpha$ levels were quantified using singleplex bead immunoassay analysis

Results: The average TNF- $\alpha$ level in POAG samples was $2.72 \pm 1.5 \mathrm{pg} / \mathrm{mL}$ (mean $\pm \mathrm{SD}$ ). The average TNF- $\alpha$ level in normal samples was $1.59 \pm 0.46 \mathrm{pg} / \mathrm{mL}$ (mean \pm SD). Significant increase of TNF- $\alpha$ levels in POAG samples was noted in comparison to normal samples $(P<0.001)$.

Conclusion: TNF- $\alpha$ levels are elevated in aqueous in patients with POAG compared to normal subjects based on highly sensitive Luminex ${ }^{\circledR}$ bead immunoassay and may be a reliable biomarker in the progression of glaucoma.

Keywords: TNF- $\alpha$, POAG, aqueous humor, cytokine

\section{Introduction}

Tumor necrosis factor alpha (TNF- $\alpha$ ), a macrophage/monocyte derived pluripotent cytokine, is associated with tissue ischemia, neuronal damage, and remodeling, ${ }^{1}$ and increased levels signify neuronal damage after brain trauma. ${ }^{2,3}$

TNF- $\alpha$ mRNA is upregulated in the retina, with retinal ganglion cell and oligodendrite cell loss and consecutive optic atrophy, in a mouse model of glaucoma. ${ }^{4}$ Elevated TNF- $\alpha$ levels in aqueous in this model was attributed to release from damaged retinal ganglion cells (RGC) and oligodendrocytes secondary to high intraocular pressure. ${ }^{5}$ In humans, immunohistochemical analysis revealed elevated TNF- $\alpha$ expression in the optic nerve and the retina of glaucomatous eyes. ${ }^{6,7}$ However, the physiological level of TNF- $\alpha$ in aqueous humor of normal and glaucomatous eyes is unknown.

Estimation of TNF- $\alpha$ may serve as a biomarker in both undiagnosed early glaucoma as well as in primary open angle glaucoma (POAG). Additionally, evaluating TNF- $\alpha$ levels in glaucoma patients may also help monitor disease progression and the effectiveness of therapy. We evaluated TNF- $\alpha$ levels in aqueous samples of patients with POAG and compared them to controls with singleplex bead immunoassay. 


\section{Methods}

\section{Subjects}

Our study group consisted of 32 eyes belonging to $32 \mathrm{POAG}$ patients (mean age $\pm \mathrm{SD}, 68.6 \pm 10.7$ years; male/female, 17/15) who underwent cataract extraction, trabeculectomy, or aqueous shunt implantation at the University of Florida, Jacksonville. Patients with secondary etiologies, such as pseudoexfoliation or pigmentary glaucoma, were excluded from the study. Thirty-two normal subjects (mean age \pm SD, $70.3 \pm 10.3$ years; male/female, 13/19), who underwent routine cataract surgery, acted as controls. Subjects in both groups with diabetes, macular degeneration, or systemic inflammatory conditions were excluded. All study participants underwent a comprehensive ophthalmic examination, including visual acuity, measurement of intraocular pressure, slit lamp examination, and fundus biomicroscopy. At the time of surgery, all patients with glaucoma were being treated with intraocular pressure lowering agents.

\section{Aqueous sample collection}

Aqueous sample collections were performed using a standard sterilization procedure. Sample collection protocol was approved by the institutional review board at the University of Florida, Jacksonville. Fifty to $100 \mu \mathrm{L}$ of undiluted aqueous humor samples were collected, from each eye, in a tuberculin syringe prior to the beginning of surgery. Inadvertent touching of intraocular tissues was avoided to prevent contamination of aqueous samples with blood. After collection, samples were stored at $-80^{\circ} \mathrm{C}$.

\section{Use of immunobead assay for TNF- $\alpha$ analysis}

Samples were diluted 1:2 and processed for TNF- $\alpha$ analysis using singleplex bead immunoassay (Invitrogen Corporation, USA). Standards were reconstituted and serially diluted, per the manufacturer's instructions. To each well of a 96-well microtiter plate, $25 \mu \mathrm{L}$ of bead and wash solutions were added and incubated for 30 seconds. After the incubation time, supernatant was aspirated, using vacuum manifold; $50 \mu \mathrm{L}$ of incubation buffer were added to each well, followed by $50 \mu \mathrm{L}$ of assay diluent and $50 \mu \mathrm{L}$ of the aqueous sample. Diluted standards were added to the designated wells and the plate was incubated for 2 hours at room temperature on an orbital shaker at $250-500 \mathrm{rpm}$. After incubation, the liquid was removed and the excess beads were washed off. Furthermore, $100 \mu \mathrm{L}$ of detector antibody was added to each well and incubated on an orbital shaker at room temperature for 1 hour.
Excess detector antibodies were removed, followed by the addition of substrate complex (S-RPE, Streptavidin R-Phycoerythrin), and the fluorescence was measured using the Luminex $100^{\mathrm{TM}}$ IS fluoroanalyzer (Luminex Inc., Austin, TX) after 30 minutes of incubation at room temperature. For each reaction, both negative and positive controls were included on the microtiter plate. To ensure proper assay, a known concentration of human recombinant TNF- $\alpha$ was included in each run as a positive control.

\section{Analysis of TNF- $\alpha$ levels}

A graphical plot was constructed, using standard concentration against standard fluorescence. The curve fitting linear regression algorithm was performed using GraphPad InStat data analysis software (Graphpad, San Diego, CA). The concentration of TNF- $\alpha$ level was extracted from standard curve and expressed as $\mathrm{pg} / \mathrm{mL}$. The effect of dilution was considered in determining the final values.

\section{Statistical analysis}

Statistical analysis was performed with GraphPad InStat and Minitab ${ }^{\circledR} 13$ (Minitab, State College, PA) statistical packages. A $t$-test was used to compare the intergroup variation in TNF- $\alpha$ levels between normal and glaucoma samples. A $P$-value of $<0.05$ was considered statistically significant.

\section{Results}

TNF- $\alpha$ levels were determined in aqueous of 32 glaucomatous eyes and 32 control eyes using a highly sensitive microparticle bead based immunoassay. To ensure the accuracy of the assay, 25 to $100 \mathrm{pg} / \mathrm{mL}$ of known concentration of human recombinant TNF- $\alpha$ was used in each assay as internal control.

The mean age of glaucoma patients was $68.6 \pm 10.7$ years and that of the controls was $70.3 \pm 10.3$ years. Among the glaucoma samples, 17 patients were male and 15 patients were female and in the controls, 13 were male and 19 were female. All glaucoma samples were from POAG patients with varying disease severity. The glaucoma samples were well matched to control samples in age and gender with no significant difference (Table 1).

The average TNF- $\alpha$ level observed in glaucoma samples was $2.72 \pm 1.5 \mathrm{pg} / \mathrm{mL}$ (mean $\pm \mathrm{SD}$ ), with a range of 1.25 to $9.0 \mathrm{pg} / \mathrm{mL}$. The average TNF- $\alpha$ level observed in normal samples was $1.59 \pm 0.46 \mathrm{pg} / \mathrm{mL}$ (mean $\pm \mathrm{SD}$ ), with a range of 0.806 to $2.456 \mathrm{pg} / \mathrm{mL}$ (Figure 1). We observed a significant increase in TNF- $\alpha$ levels in the glaucomatous samples in comparison to the normal samples $(P<0.001, t$-test) (Figure 2$)$. 
Table I Demographic data of subjects with glaucoma and normal samples

\begin{tabular}{llll}
\hline & Normal $(\mathbf{n}=\mathbf{3 2})$ & Glaucoma $(\mathbf{n}=\mathbf{3 2})$ & $\chi^{2}$ test $P$ - Value \\
\hline Sex, male & 13 & 17 & \\
Sex, female & 19 & 15 & $\chi^{2}(P=0.3)$ \\
Age $(40-70)$ & 18 & 16 & \\
Age $(70-90)$ & 14 & 16 & $\chi^{2}(P=0.6)$ \\
\hline
\end{tabular}

\section{Discussion}

Glaucoma, a common cause of blindness that affects millions of people, is characterized by optic nerve atrophy from progressive apoptotic neuronal degeneration secondary to elevated intraocular pressure (IOP) over a long period of time. Retinal ganglion cells, in response to stress mediated through elevated IOP, undergo apoptosis with consecutive atrophy.

Cytokine release and oxidative stress contribute to glaucomatous degeneration. ${ }^{8} \mathrm{TNF}-\alpha$, a potent immunomodulatory cytokine, is upregulated in a patient with posttraumatic brain injury. ${ }^{1,2}$ Poor outcome is associated with elevated levels, while inhibition of the TNF- $\alpha$ release limits brain damage. ${ }^{3}$ TNF- $\alpha$ acts on TNF- $\alpha$ receptor 1 (p55) and mediates apoptosis through a caspase-induced pathway. The addition of exogenous TNF- $\alpha$ following ischemic cerebral injury exacerbated neuronal damage, while blocking TNF- $\alpha$ was found to be neuroprotective in a rat model. ${ }^{3}$

In the glaucomatous eye, an upregulation of TNF- $\alpha$ protein, an elevated TNF- $\alpha$ gene expression in glial cells, and a TNF- $\alpha$ receptor 1 in retinal ganglion cells, were noted. ${ }^{7}$ Intraocular pressure induced apoptosis of retinal ganglion cells (RGC), through caspase- 3 and caspase- 8 activation. ${ }^{9}$ In animal models, TNF- $\alpha$ induced apoptosis was inhibited with a TNF- $\alpha$ neutralizing antibody. ${ }^{5}$

Neurodegenerative disorders, such as Parkinson's disease, ${ }^{10}$ Alzheimer's disease, ${ }^{11}$ and multiple sclerosis, ${ }^{12}$ have elevated levels of TNF- $\alpha$. The pathogenesis of these disorders, as well as glaucoma, is a result of a neuroinflammatory process. ${ }^{13-15}$ Pro-inflammatory cytokines, such as TNF- $\alpha$, may contribute to this process.

In a previous study by Sawada et al, ${ }^{16} \mathrm{TNF}-\alpha$ was evaluated in aqueous samples of 84 glaucoma-affected eyes and 79 eyes from the control group, using an enzyme-linked immunosorbent assay (ELISA). TNF- $\alpha$ was detected in only 19 eyes, with an overall increased rate of detection in glaucomatous eyes compared to control eyes. However, the slightly elevated TNF- $\alpha$ aqueous levels in POAG and normal tension glaucoma were not found to be statistically significant, while those with exfoliation glaucoma showed

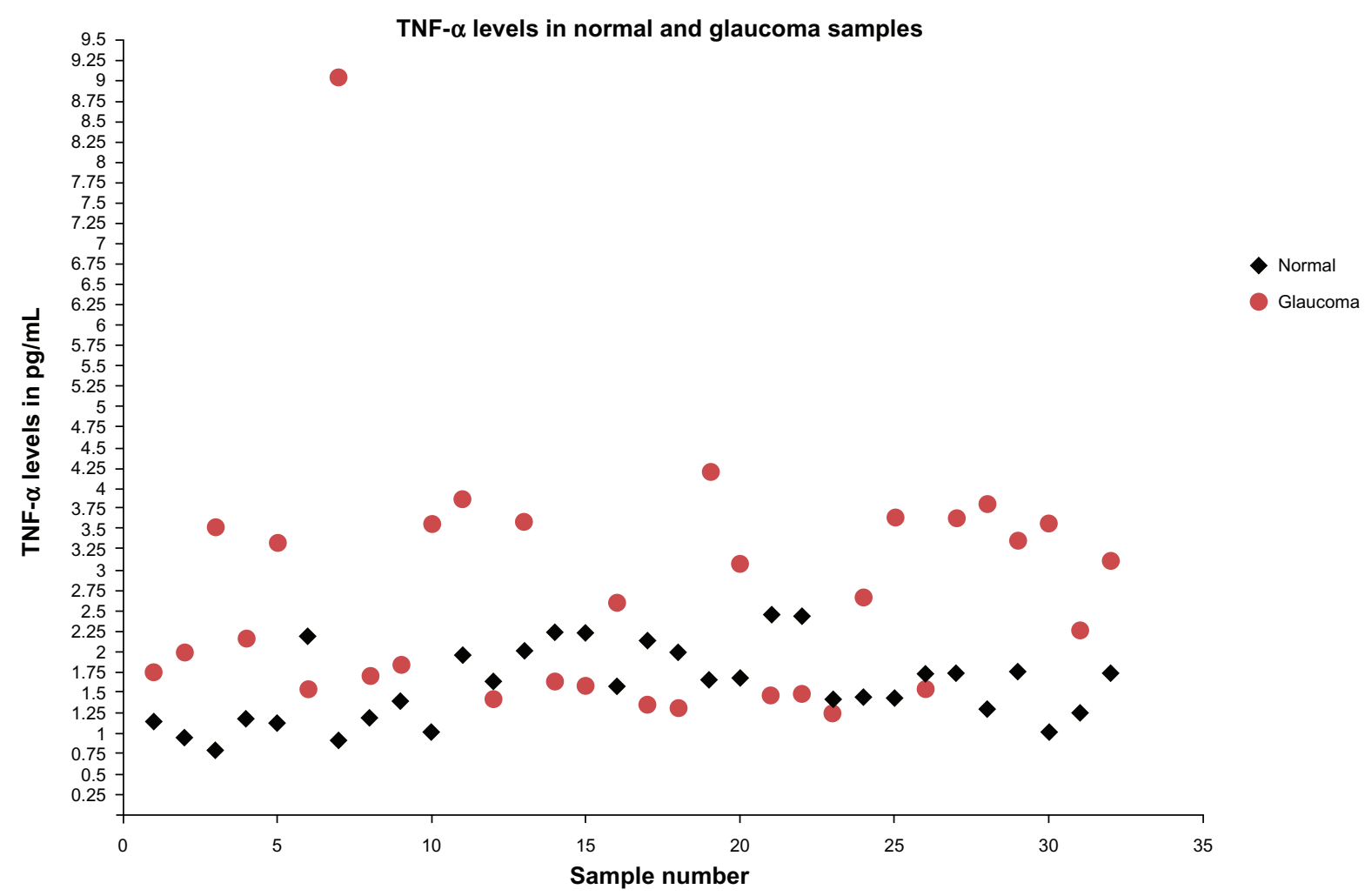

Figure I TNF- $\alpha$ levels in normal and glaucoma samples. The sample number is shown on the $\mathrm{X}$-axis and the TNF- $\alpha$ levels expressed in $p g / m L$ are shown on the $Y$-axis. Abbreviation: TNF- $\alpha$, tumor necrosis factor alpha. 


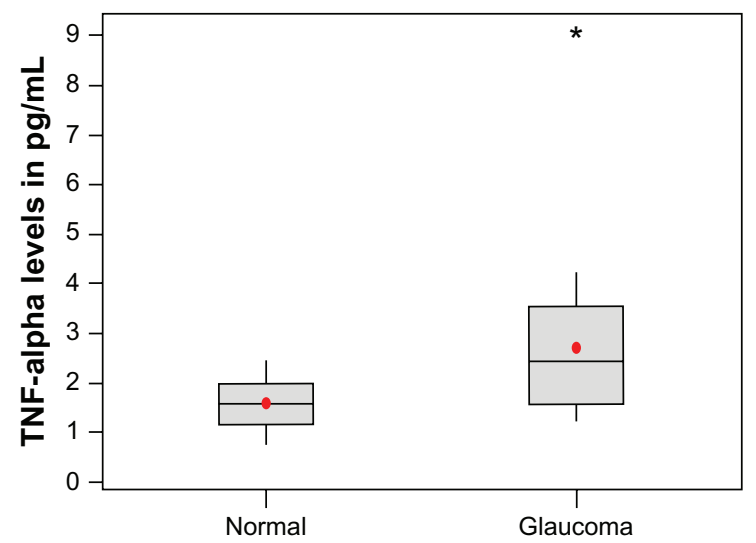

Figure 2 Comparative analysis of TNF- $\alpha$ levels between normal and glaucoma samples. mean values are represented by solid circles.

Note: Significant difference was observed between normal versus glaucoma samples $(P<0.00$ I $)$

Abbreviation: TNF- $\alpha$, tumor necrosis factor alpha.

a statistically significant increase compared to control eyes. Kuchtey et $\mathrm{al}^{17}$ further elucidated TNF- $\alpha$ levels in aqueous humor, with multiplex microparticle-based immunoassay, but were unable to detect TNF- $\alpha$ in glaucomatous eyes.

In the present study, the more sensitive singleplex bead immunoassay was used to determine values in normal eyes as well as eyes with primary open-angle glaucoma. We found the average level of TNF- $\alpha$ in normal samples to be $1.09 \mathrm{pg} /$ $\mathrm{mL}$, compared to $3.35 \mathrm{pg} / \mathrm{mL}$ in glaucomatous eyes. Though most of the patients in this study had well-controlled IOP, seven patients had advanced glaucoma and underwent trabeculectomy, or valve placement, for IOP refractory to medical therapy.

Though vitreous levels of TNF- $\alpha$ are likely to be higher, due to its proximity to the retina, a small proportion of TNF- $\alpha$ diffuses to the aqueous humor. Sensitive immunoassay that detects these levels may identify the presence of glaucomatous damage in a quantitative manner. Using this bead based immunoassay, the TNF- $\alpha$ levels can be estimated even at low levels. Factors such as severity of glaucoma and use of topical medications may also influence TNF- $\alpha$ levels. This aspect of the study must be further evaluated in a larger cohort study.

In summary, TNF- $\alpha$ levels were elevated in aqueous in patients with POAG compared to normal subjects, based on highly sensitive Luminex ${ }^{\circledR}$ bead immunoassay.

Clinical Ophthalmology

\section{Publish your work in this journal}

Clinical Ophthalmology is an international, peer-reviewed journal covering all subspecialties within ophthalmology. Key topics include: Optometry; Visual science; Pharmacology and drug therapy in eye diseases; Basic Sciences; Primary and Secondary eye care; Patient Safety and Quality of Care Improvements. This journal is indexed on Submit your manuscript here: http://www.dovepress.com/clinical-ophthalmology-journal

\section{Disclosure}

The authors report no conflicts of interest in this work.

\section{References}

1. Muñoz-Fernández MA, Fresno M. The role of tumor necrosis factor, interleukin 6, interferon-gamma, and inducible nitric oxide synthase in the development and pathology of the nervous system. Prog Neurobiol. 1998;56(3):307-340.

2. Ertel W, Keel M, Bonaccio M, et al. Release of anti-inflammatory mediators after mechanical trauma correlates with severity of injury and clinical outcome. J Trauma. 1995;39(5):879-887.

3. Shohami E, Bass R, Wallach D, Yamin A, Gallily R. Inhibition of tumor necrosis factor alpha (TNF- $\alpha$ ) activity in rat brain is associated with cerebroprotection after closed head injury. $J$ Cerebr Blood Flow Metab. 1996;16(3):378-384.

4. Nakazawa T, Nakazawa C, Matsubara A, et al. Tumor necrosis factor-alpha mediates oligodendrocyte death and delayed retinal ganglion cell loss in a mouse model of glaucoma. J Neurosci. 2006;26(49):12633-12641.

5. Tezel G, Wax MB. Increased production of tumor necrosis factoralpha by glial cells exposed to stimulated ischemia or elevated hydrostatic pressure induces apoptosis in cocultured retinal ganglion cells. J Neurosci. 2000;20(23):8693-8700.

6. Yuan L, Neufeld AH. Tumor necrosis factor-alpha: a potentially neurodestructive cytokine produced by glia in the human glaucomatous optic nerve head. Glia. 2000;32(1):42-50.

7. Tezel G, Li LY, Patil RV, Wax MB. TNF-alpha and TNF-alpha receptor-1 in the retina of normal and glaucomatous eyes. Invest Ophthalmol Vis Sci. 2001;42(8):1787-1794.

8. Tezel G. Oxidative stress in glaucomatous neurodegeneration: mechanisms and consequences. Prog Retin Eye Res. 2006;25(5):490-513.

9. McKinnon SJ, Lehman DM, Kerrigan-Baumrind LA, et al. Caspase activation and amyloid precursor protein cleavage in rat ocular hypertension. Invest Ophthalmol Vis Sci. 2002;43(4):1077-1087.

10. Scalzo P, Kümmer A, Cardoso F, Teixeira AL. Increased serum levels of soluble tumor necrosis factor-alpha receptor-1 in patients with Parkinson's disease. J Neuroimmunol. 2009 Nov 30;216(1-2):122-125.

11. Alvarez A, Cacabelos R, Sanpedro D, García-Fantini M, Aleixandre M. Serum TNF-alpha levels are increased and correlate negatively with free IGF-I in Alzheimer disease. Neurobiol Aging. 2007;28(4):533-536.

12. Tsukada N, Miyagi K, Matsuda M, Yanagisawa N, Yone K. Tumor necrosis factor and interleukin-1 in the CSF and sera of patients with multiple sclerosis. J Neurol Sci. 1991;104(2):230-234.

13. Ahmed F, Brown KM, Stephan DA, Morrison JC, Johnson EC, Tomarev SI. Microarray analysis of changes in mRNA levels in the rat retina after experimental elevation of intraocular pressure. Invest Ophthalmol Vis Sci. 2004;45(4):1247-1258.

14. Hunot S, Hirsch EC. Neuroinflammatory processes in Parkinson's disease. Ann Neurol. 2003;53 Suppl 3:S49-S58; discussion S58-S60.

15. Heneka MT, O’Banion MK. Inflammatory processes in Alzheimer's disease. J Neuroimmunol. 2007;184(1-2):69-91.

16. Sawada H, Fukuchi T, Tanaka T, Abe H. Tumor necrosis factor-alpha concentrations in the aqueous humor of patients with glaucoma. Invest Ophthalmol Vis Sci. 2010;51(2):903-906.

17. Kuchtey J, Rezaei KA, Jaru-Ampornpan P, et al. Multiplex Cytokine Analysis Reveals Elevated Concentration of Interleukin-8 in Glaucomatous Aqueous Humor. Invest Ophthalmol Vis Sci. 2010;51(12):6441-6447.

\section{Dovepress}

PubMed Central and CAS, and is the official journal of The Society of Clinical Ophthalmology (SCO). The manuscript management system is completely online and includes a very quick and fair peer-review system, which is all easy to use. Visit http://www.dovepress.com/ testimonials.php to read real quotes from published authors. 